\title{
STUDIES OF THE BLOOD IN BERIBERI *
}

\author{
SURGEON-INSPECTOR I. YOSHIKAWA $\dagger$ \\ AND \\ FLEETSURGEONS $\mathrm{K}$. YANO AND $T$. NEMOTO \\ TOKYO, JAPAN
}

\section{REFRACTOMETRIC INVESTIGATION OF THE SERUM}

Refractometric investigation of the blood was carried out for the first time by Strubel1 ${ }^{1}$ in 1900 . He considered the procedure available for measuring the osmotic pressure of the blood, but Reiss, ${ }^{2}$ after two years' thorough study of the subject (1901-1902), found that the refractive index bears no relation to osmotic pressure, but that refractometric estimation is practically equivalent to a quantitative determination of protein in the blood. To prove that such a relation exists, Reiss cited a table of results of Vaucher, ${ }^{3}$ in which he compared the figures obtained by refraction with those obtained by weighing the proteins.

According to Reiss, the quantity of nonprotein substances in the blood shows no remarkable variation, although the contrary is generally believed to be true. The freezing point of the blood, for example, is normally $0.56 \mathrm{C}$., and even in extreme cases it does not fall below 0.49 , or exceed 0.71 . In the case of uremia, however, he notes that the refraction coefficient is influenced by the accumulation of urea and other substances in the blood, and that consequently the refractometric estimation of proteins is, in uremic cases, not reliable.

Strauss, ${ }^{4}$ in 1904, used the refractometric method, and it has since been taken up by others. ${ }^{5}$ It is now considered by many to be a simple

* Submitted for publication April 2, 1917.

* From the Laboratory of the Naval Medical College, Tokyo.

* Read before the periodical meeting of the Beriberi Research Committee, 1916.

i A member of the Beriberi Research Committee of the Japanese government.

1. Strubell, A.: Ueber refraktometrische Blutentersuchungen, München. med. Wchnschr., 1902, 49, 616.

2. Reiss, E.: Die refraktometrische Blutuntersuchung und ihre Ergebnisse f. die Physiologie und Pathologie des Menschen. Ergebn. d. inn. Med., 1913, 10, 531 .

3. Vaucher, E.: L'hydrémie des brightques et des cardiaques oedémateux Paris, 1911.

4. Strauss, H.: Demonstration der refraktometrischen Blutuntersuchung, Deutsch, med. Wchnschr., 1905, 31, 83.

5. Neuberg, C.: Der Harn. Berlin, 1911 ; Tranter, C. L., and Rowe, A. H.: The Refractometric determination of Albumin, Globulin, and Nonprotein in Normal Human Blood Serum, Jour. Am. Med. Assn., 1915, 65, 1433; Legueu, E. : Nutzen der Anwendung der Harnstoffsekretionskonstante bei den Prostatikern, Berl. klin. Wchnschr., 1913, 50, 1741. 
and convenient method for the estimation of the protein content of the serum.

The present article gives the results of a recent refractometric investigation of the serum of beriberi patients in the Tokyo Municipal Charity Hospital. Abbe's Universalrefraktometer was used for the experiments, as Pulfrich's Eintauchrefraktometer, which is generally recommended, was not available.

We recognized the desirability of taking the blood at a definite time each day, owing to the influence of the ingestion of food on the protein content, but as all of the patients examined were outpatients, it was

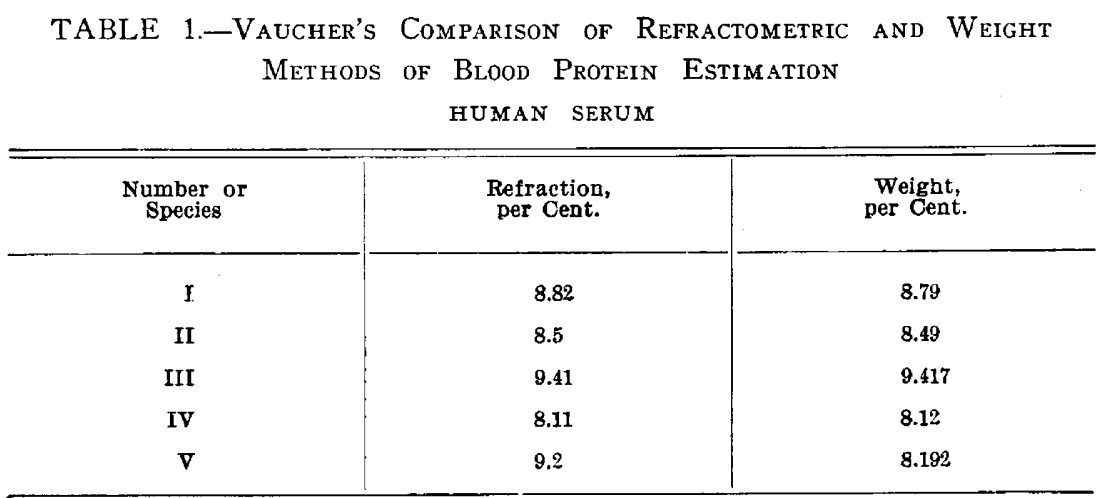

ANIMAL SERUM

\begin{tabular}{l|l|l}
\hline Ox & 8.15 & 8.14 \\
Ox & 8.4 & 8.384 \\
Horse & 8.31 & 8.28 \\
Pig & 7.88 & 7.85 \\
Pig & 8.63 & 8.58 \\
\hline
\end{tabular}

not always possible to observe this rule. We fixed the time at $11 \mathrm{a} . \mathrm{m}$. and took the blood as near that time as possible. The blood was received in a capillary tube and put into a refrigerator until coagulation had taken place. Any serum which was found to be tinged with red was discarded. A temperature of $17.5 \mathrm{C}$. was maintained by means of the regulator connected with the apparatus. The examinations were made almost exclusively on recently admitted patients, since the use of aperients, such as sulphate of magnesia, is thought to increase somewhat the concentration of the blood.

The results of our examinations may be tabulated as shown in Table 2 . 
TABLE 2.-Authors' Estimations

\begin{tabular}{|c|c|c|c|c|c|c|}
\hline No. & Name & Sex* & Age & $\begin{array}{l}\text { Length of rime } \\
\text { between Onget and } \\
\text { Examination }\end{array}$ & $\begin{array}{l}\text { Refractive } \\
\text { Index }\end{array}$ & $\begin{array}{l}\text { Protein, } \\
\text { per Cent. }\end{array}$ \\
\hline 1 & Y. Z. & $\sigma$ & 24 & 1 month & 1.3540 & 10.4 \\
\hline 2 & N. M. & $0^{*}$ & . & n........ & 1.3539 & 10.4 \\
\hline 3 & о. H. & $\sigma^{\circ}$ & 18 & n......... & 1.3526 & 9.5 \\
\hline 4 & Y. M. & $\sigma^{*}$ & 19 & 10 days & 1.3525 & $9 . \overline{5}$ \\
\hline 5 & H. M. & $\sigma^{\prime}$ & 19 & 5 to 6 days & 1.3515 & 9.1 \\
\hline 6 & F. $\mathrm{K}$. & $\sigma^{\pi}$ & 22 & 5 to 6 days & 1.3515 & 9.1 \\
\hline 7 & S. M. & $0^{\pi}$ & 23 & 3 weeks & 1.3512 & 8.9 \\
\hline 8 & N. Y. & $\sigma^{*}$ & 56 & 4 months & 1.3510 & 8.8 \\
\hline 9 & T. T. & $\sigma$ & 55 & 3 weeks & 1.3505 & 8.5 \\
\hline 10 & Y. T. & $\sigma$ & 29 & 3 months & 1.3498 & 8.1 \\
\hline 11 & S. R. & $\sigma^{\pi}$ & 20 & 20 days & 1.3498 & 8.1 \\
\hline 12 & K. N. & 8 & 20 & n......... & 1.3488 & 7.5 \\
\hline 13 & o. T. & 0 & 37 & n........ & 1.3485 & 7.4 \\
\hline 14 & K. T. & $\sigma^{x}$ & 43 & 4 months & 1.3477 & 6.8 \\
\hline 15 & M. T. & $\sigma^{\prime}$ & 27 & n.......... & 1.3475 & 6.8 \\
\hline 16 & F. S. & $\delta$ & 54 & 1 month & 1.3472 & 6.6 \\
\hline 17 & M. 'T. & $\sigma^{\circ}$ & 51 & n........ & 1.3470 & 6.5 \\
\hline 18 & T. S. & $\sigma^{*}$ & 16 & 1 week & 1.3468 & 6.3 \\
\hline 19 & T. S. & $\delta$ & 49 & $\ldots \ldots \ldots$ & 1.3465 & 6.1 \\
\hline 20 & Y. S. & $q$ & 24 & 2 weeks & 1.3520 & 9.4 \\
\hline 21 & s. K. & \% & 28 & 2 weeks & 1.3517 & 9.2 \\
\hline 22 & s. T. & q & 41 & 1 month & 1.3506 & 8.6 \\
\hline 23 & s. K. & $q$ & 61 & $11 / 2$ months & 1.3502 & 8.4 \\
\hline 24 & O. K. & 9 & 29 & 1 month & 1.3500 & 8.2 \\
\hline 25 & s. $\mathbf{K}$. & & 20 & 5 to 6 days & 1.3499 & 8.2 \\
\hline 26 & S. S. & $q$ & 23 & $\ldots \ldots \ldots$ & 1.3495 & 7.9 \\
\hline 27 & Y. T. & ㅇ & 43 & 6 months & 1.3495 & 7.9 \\
\hline 28 & H. I. & $q$ & 34 & 2 months & 1.3495 & 7.9 \\
\hline 29 & I. $\mathrm{Y}$. & q & 22 & 1 month & 1.3493 & 7.8 \\
\hline 30 & K. 'T. & 8 & 42 & 1 week & 1.3489 & 7.6 \\
\hline 31 & K. I. & \& & 33 & 40 days & 1.3489 & 7.6 \\
\hline 32 & A. $\mathbf{T}$. & q & 24 & 5 to 6 days & 1.3486 & 7.4 \\
\hline 33 & I. $\mathrm{N}$. & 9 & 47 & $\ldots \ldots \ldots$ & 1.3480 & 7.0 \\
\hline 34 & S. $\mathbf{M}$. & q & 41 & 2 months & 1.3479 & 7.0 \\
\hline
\end{tabular}

$* \sigma=$ male; $q=$ female. 
As the table shows, the quantity of protein in the serum of thirtyfour patients with beriberi, as computed from the refractive index, varied from 6.1 to 10.4 per cent. For purposes of comparison, we give, in Table 3 , the results of several other authors.

TABlE 3.-Refractometric Estimatlons of Other Authors for COMPARISON

\begin{tabular}{|c|c|c|}
\hline Autbor & Refractive Index & Protein, per Cent. \\
\hline Reiss................................ & $1.34802-1.35145$ & $7.0-9.0$ \\
\hline Strauss, Chajes............ & $1.3480-1.3510$ & $7.0-8.7$ \\
\hline Engel........... & $1.3487-1.3522$ & $7.4-9.4$ \\
\hline Martins................ & $1.3480-1.3520$ & $7.0-9.0$ \\
\hline Goldammer...... & $1.34724-1.35169$ & $6.6-9.1$ \\
\hline Böhme......... & $1.3476-1.3512$ & $6.8-8.9$ \\
\hline Winternitz........ & $1.34940-1.35058$ & $7.8-8.5$ \\
\hline Widal, Bernard, vaucher............ & $1.34904-1.35042$ & $7.6-8.4$ \\
\hline Tranter, Rowe.. & n............ & $6.7-8.7$ \\
\hline
\end{tabular}

Table 4.-Serum of Healthy Persons

\begin{tabular}{|c|c|c|c|c|c|}
\hline Number & Name & $\operatorname{Sex}^{*}$ & Age & Refractive Index & $\begin{array}{c}\text { Protein, per } \\
\text { Cent. }\end{array}$ \\
\hline 1 & o. C. & $\sigma$ & 20 & 1.3507 & 8.6 \\
\hline 2 & Y. $\mathbf{K}$. & $\sigma^{\circ}$ & 36 & 1.3483 & 7.2 \\
\hline 3 & H. I. & $\sigma$ & 32 & 1.3483 & 7.2 \\
\hline 4 & I. $\mathbf{K}$. & $\sigma$ & 56 & 1.3477 & 6.9 \\
\hline 5 & Y. M. & $\sigma^{\pi}$ & 10 & 1.3476 & 6.8 \\
\hline 6 & M. T. & $\sigma^{\pi}$ & 34 & 1.3473 & 6.6 \\
\hline 7 & T. N. & $\sigma$ & 21 & 1.3469 & 6.4 \\
\hline 8 & T. $\mathbf{Z}$. & $\sigma$ & 30 & 1.3468 & 6.3 \\
\hline 9 & I. 0 . & q & 17 & 1.3490 & 7.6 \\
\hline 10 & M. S. & q & 68 & 1.3486 & 7.4 \\
\hline 11 & K. T. & 우 & 43 & 1.3479 & 7.0 \\
\hline 12 & T. F. & q & 16 & 1.3478 & 6.9 \\
\hline 13 & Y. T. & 우 & 30 & 1.3475 & 6.8 \\
\hline 14 & O. H. & ㅇ & 28 & 1.3469 & 6.4 \\
\hline 15 & K. F. & q & 17 & 1.3468 & 6.4 \\
\hline
\end{tabular}

$* \sigma^{x}=$ male; $q=$ female.

The figures for protein content in Table 3 vary from 6.6 to 9.4 per cent. If we assume that the normal protein content is found between 6.6 and 9.4 per cent., then the protein content of the beriberi blood 
examined conformed in half the cases with the minimum normal figure but in the other half considerably exceeded the maximum normal figure. We examined as controls the serums of fifteen healthy Japanese. The results are given in Table 4 .

The number of persons examined as controls was not large enough to warrant our accepting the figures obtained as representing the standard in healthy persons, yet it seems probable that the standard approaches these figures. A comparison of the figures in Table 4 with those of Table 2 apparently shows that the refractive index of the serum of persons suffering from beriberi is in general higher than that of normal persons. From Table 5, in which the average amount of protein for healthy and for beriberi serum is compared, it is clear that the quantity of protein in beriberi serum is greater than that of normal serum, irrespective of sex.

TABLE 5.-Comparison of Serums from Normal Persons and Beriberi Patients

\begin{tabular}{|c|c|c|c|}
\hline & $\begin{array}{c}\text { Average in } \\
\text { Male, } \\
\text { per Cent. }\end{array}$ & $\begin{array}{c}\text { Average in } \\
\text { Female, } \\
\text { per Cent. }\end{array}$ & $\begin{array}{c}\text { Total } \\
\text { Average, } \\
\text { per Cent. }\end{array}$ \\
\hline Healthy serum......................... & 7.0 & 6.96 & 6.92 \\
\hline Beriberi serum........................ & 8.11 & 8.06 & 8.01 \\
\hline
\end{tabular}

\section{SUMMARY}

The investigation reported in the foregoing account was made on the assumption that the rise in the refractive index of the serum in beriberi is dependent only on the increase of its protein content. It is possible, however, that it is also due to the retention of nonprotein substances. We may state in conclusion that the refractive index of the serum of persons suffering from beriberi shows often no deviation from the normal, but not inf requently a marked rise.

\section{DETERMINATION OF UREA IN THE BLOOD AND OF AMBARD'S COEFFICIENT}

- Urea in the Blood.-Although the elimination of urea in beriberi has frequently been the subject of study, so far no results of studies on urea in the blood in these cases have been reported. The reason is probably that for ordinary methods a comparatively large quantity of blood is required. Moreover, the necessarily complicated technic makes such study impracticable. Both of these obstacles are removed, 
however, in the method of determination of urea in the blood by means of urease reported by Van Slyke, Zacharias, and Cullen ${ }^{6}$ in 1914.

The results reported in the present paper were obtained by estimations of urea in the blood, according to the urease method, of both inpatients and outpatients of the Tokyo Municipal Charity Hospital. The urease was prepared by Bertrand's method, because in a preliminary comparison of samples of urease prepared $(a)$ by the method of Hahn and Saphra, ${ }^{7}(b)$ by the method of Van Slyke, Zacharias, and Cullen, ${ }^{6}$ and $(c)$ by Bertrand's method, ${ }^{3}$ the urease prepared by the latter method was found most active. The determination of the quantity of urea, however, was made after Hahn and Saphra, because their method was simplest. The blood was taken from inpatients

TABLE 6.-Amount of Urea in Beriberi Blood

\begin{tabular}{|c|c|c|c|c|c|c|c|c|c|c|c|}
\hline \multicolumn{8}{|c|}{ Outpatients } & \multicolumn{4}{|c|}{ Inpatients } \\
\hline No. & Name & Sex $\uparrow$ & $\begin{array}{c}\text { Urea, } \\
\text { per } \\
\text { Mille }\end{array}$ & No. & Name & $\operatorname{Sex} t$ & $\begin{array}{c}\text { Urea, } \\
\text { per } \\
\text { Mille }\end{array}$ & No. & Name & Sex $t$ & $\begin{array}{c}\text { Urea, } \\
\text { per } \\
\text { Mille }\end{array}$ \\
\hline 1 & A. & $\sigma$ & 0.2 & 12 & M. & $\sigma$ & 0.4 & 23 & $\mathrm{U}$. & $\sigma^{\pi}$ & 0.23 \\
\hline 2 & K. & $\sigma$ & 0.3 & 13 & s. & 0 & 0.41 & 24 & 0 & 8 & 0.24 \\
\hline 3 & A. & $\sigma^{*}$ & 0.3 & 14 & $\mathbf{Y}$. & $\sigma$ & 0.42 & 25 & o. & 우 & 0.25 \\
\hline 4 & $\mathbf{M}$ & $\sigma^{x}$ & 0.32 & 15 & $\mathbf{K}$. & $\sigma^{*}$ & 0.45 & 26 & s. & $\sigma$ & 0.28 \\
\hline 5 & $\mathbf{K}$. & $\sigma^{*}$ & 0.32 & 10 & M. & $\sigma$ & 0.46 & 27 & o. & $q$ & 0.29 \\
\hline 6 & $\mathrm{~T}$. & $q$ & 0.32 & 17 & H. & $\sigma$ & 0.49 & 28 & s. & q & 0.30 \\
\hline 7 & o. & $\sigma$ & 0.32 & 18 & $\mathrm{~K}$. & 0 & 0.50 & 29 & 0. & $\sigma$ & 0.33 \\
\hline 8 & s. & $\sigma^{\circ}$ & 0.34 & 19 & K. & $\sigma^{\circ}$ & 0.50 & 30 & $\mathrm{H} . *$ & $0^{7}$ & 0.45 \\
\hline 9 & o. & $d$ & 0.36 & 20 & M. & 8 & 0.52 & 31 & A.* & $\sigma^{*}$ & 1.08 \\
\hline 10 & F. & $\sigma^{2}$ & 0.37 & 21 & 0 & $\sigma$ & 0.6 & 32 & H.* & $\sigma$ & 1.1 \\
\hline 11 & K. & $\sigma^{2}$ & 0.38 & 22 & S. & 9 & 0.6 & 33 & $\mathbf{K} . *$ & $\sigma^{\circ}$ & 5.79 \\
\hline
\end{tabular}

* These patients were severe cases. A. and $K$. died from cardiac failure, not infrequent in beriberi. The remaining two were discharged atter gradual recovery.

$\dagger \sigma^{*}=$ male; $q=$ female.

before breakfast and from outpatients at 11 a. $m$. The results are given in Table 6.

The quantity of urea in the twenty-two outpatients varied from 0.2 to $0.6 \mathrm{gm}$. per liter, an average of 0.3 to 0.4 being general. In the seven mild house cases, the quantity varied from 0.23 to $0.33 \mathrm{gm}$. per

6. Van Slyke, D. D., Zacharias, G., and Cullen, G. E.: Die Darstellung fester Urease und ihre Verwendung zur quantitativen Bestimmung von Harnstoff im Harn, Blut, und in der Zerebrospinalflüssigkeit, Deutsch. med. Wchnschr., 1914, 40, 1219 .

7. Hahn, A., and Saphra, J.: Ein einfache für die Praxis geeignete Methode zur quantitativen Bestimmung des Harnstoffs im Urin, Deutsch. med. Wchnschr, 1914, 40, 430.

8. Bertrand: Practical Physiological Chemistry (Japanese translation). 
liter. Three out of four severe house cases showed a considerable retention of urea $-5.79 \mathrm{gm}$. per liter in one case.

Table 7 gives the figures obtained by several workers for determinations of urea in healthy blood.

Apparently, then, the normal amount of urea in the blood varies from 0.2 to $0.6 \mathrm{gm}$. per liter. One of us (Nemoto) obtained practically the same figures ( 0.2 to $0.56 \mathrm{gm}$. per liter) from twenty-one patients without renal disease and two healthy persons. As shown in Table 6 , the urea content of the blood in mild cases of beriberi was within normal limits, but in severe cases it not only increased to more than $1.0 \mathrm{gm}$. per liter, but in one case rose beyond $5.0 \mathrm{gm}$. per liter. This case recalls one reported by $M$. Miura ${ }^{9}$ several years ago, in which he.estimated $5.0 \mathrm{gm}$. per liter of urea in the pleural and peritoneal effusion from a case of beriberi. Miura, however, did not estimate the urea in the blood. Such a deviation from the normal appearing in severe cases may be due to a combination of two causes: (1) lessened elimination of urine as a result of weakened heart action, and (2) increased pro-

TABLE 7.-Quantity of Urea in Healthy Bloon

\begin{tabular}{|c|c|c|}
\hline Author & Urea, Gm. yer Jite: & \\
\hline Schöndorff $\ldots \ldots \ldots \ldots \ldots \ldots \ldots \ldots \ldots \ldots \ldots$ & $0.23-0.505$ & \\
\hline Śchöndor ff...... & 1.5 & $\begin{array}{l}\text { (After the intake of a large } \\
\text { quantity of protein) }\end{array}$ \\
\hline 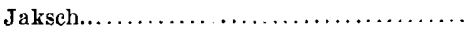 & $0.3-0.6$ & \\
\hline MeLean... & $0.2-0.5$ & (Estimated with urease) \\
\hline
\end{tabular}

tein metabolism (K. Miura, Y. Teruchi, and others), but which of these two is the main cause cannot be stated without further study.

Ambard's Coefficient.-Ambard's law with regard to kidney function has been confirmed by several workers. The details of the subject are well known and will not be recounted here. Ambard has reported that the coefficient in healthy persons ranges from 0.06 to 0.07 , and that the coefficient is higher as the deviation in kidney function is greater. McLean, ${ }^{10}$ who used urease for the determination of urea in his study of the subject, suggests 0.08 as the coefficient in healthy persons.

The results obtained by us with cases of beriberi are as shown in Table 8.

9. Miura, K.: Beriberi, 1913.

10. McLean, F. C.: The Numerical Laws Governing the Rate of Excretion of Urea and Chlorid in Man. I. An Index of Urea Excretion and the Normal Excretion of Urea and Chlorid. II. The Influence of Pathological Condition and of Drugs on Excretion, Jour. Exper. Med., 1915, 22, 212, 366. 
Ambard's coefficient ranged from 0.07 to $\mathbf{1} .36$, and in the majority of cases was above 0.09 . If we take 0.08 as the normal coefficient and our controls confirm McLean's results - then the coefficient in beriberi cases is greater than the normal. The rise of the coefficient does not necessarily coincide with the severity of clinical manifestations, for some mild cases showed a coefficient of 0.13 or 0.14 , and some severe cases 0.07 or 0.08 . It appears that in comparatively mild cases the function excreting urea may be disturbed, while in severe cases it may not be affected. It is worthy of note that in two out of four severe cases which showed a normal coefficient the patients afterward recovered, while the two patients who had a high coefficient died.

TABlE 8.-Ambard's Coefficient in Beribert Cases

\begin{tabular}{|c|c|c|c|c|c|c|c|c|c|}
\hline \multirow{2}{*}{ No. } & \multirow{2}{*}{ Name } & \multirow{2}{*}{$\begin{array}{c}\text { Nature of } \\
\text { Case }\end{array}$} & \multirow{2}{*}{$\begin{array}{l}\text { Wt., } \\
\text { Kg. }\end{array}$} & \multicolumn{2}{|c|}{ Urine, $24 \mathrm{Hrs}$. } & \multirow{2}{*}{$\begin{array}{c}\text { Urea } \\
\text { in } \\
\text { Blood, } \\
\text { Gm. } \\
\text { Liter }\end{array}$} & \multirow{2}{*}{$\begin{array}{c}\text { Urea } \\
\text { in } \\
\text { Urine, } \\
\text { per } \\
\text { Cent. }\end{array}$} & \multirow{2}{*}{$\begin{array}{l}\text { Coeff- } \\
\text { cient }\end{array}$} & \multirow{2}{*}{ Remarks } \\
\hline & & & & C.e. & Gm. & & & & \\
\hline 1 & $\mathrm{~K}$. & Severe & 60 & 1,350 & 18.79 & 5.79 & 13.91 & 1.36 & Died \\
\hline 2 & A. & Severe & 60 & 1,410 & 40.25 & 1.03 & 28.46 & 0.14 & Died \\
\hline 3 & $\mathrm{H}$. & Severe & 40 & 3,020 & 105.92 & 1.10 & 35.09 & 0.08 & Recovered \\
\hline 4 & H. & Severe & 52 & 1,605 & 32.28 & 0.45 & 20.11 & 0.07 & Recovered \\
\hline 5 & s. & Mild & 36 & 1,550 & 6.51 & 0.30 & 4.20 & 0.14 & Recovered \\
\hline 6 & o. & Mild & 51 & 384 & 8.91 & 0.29 & 23.21 & 0.08 & Recovered \\
\hline$i$ & o. & Mild & 42 & 840 & 6.92 & 0.33 & 8.23 & 0.13 & Recovered \\
\hline 8 & U. & Mild & 41 & 624 & 4.77 & 0.23 & 7.64 & 0.10 & Recovered \\
\hline 9 & o. & Mild & 36 & 864 & 8.05 & 0.25 . & 9.31 & 0.09 & Recovered \\
\hline 10 & 0. & Mild & 49 & 1,728 & 13.27 & 0.24 & 7.68 & 0.08 & Recovered \\
\hline 11 & s. & Mild & 54 & 1,152 & 12.40 & 0.28 & 10.76 & 0.09 & Recovered \\
\hline $\mathrm{C}^{*}$ & M. & Normai & 53 & 792 & 10.95 & 0.25 & 13.82 & 0.08 & \\
\hline $\mathrm{C}^{*}$ & $\mathrm{~K}$. & Normal & 48 & 1,066 & 14.11 & 0.27 & 12.01 & 0.08 & \\
\hline
\end{tabular}

These instances seem to suggest that the cardiac failure in beriberi may be due to uremia, yet the clinical symptoms in cases of cardiac failure in beriberi are quite different from those of the ordinary uremia. It is possible that in beriberi some unknown toxic substances are produced in the biood which, if excreted in the same manner as urea, do not cause death, but the accumulation of which in the blood causes heart failure. If this is true, then it is conceivable that the amelioration of the threatening symptoms of beriberi which venesection brings is the result of diminution of the unknown toxic products. Further investigation of this subject is necessary before a definite statement can be made. 
SUMMARY

1. 'The quantity of urea in the blood of beriberi patients shows, in mild cases, no deviation from the normal, but in the majority of severe cases a marked increase.

2. Ambard's coefficient is not infrequently higher than normal in beriberi; that is, the function excreting urea is frequently disturbed.

3. The disturbance of the kidney function does not necessarily coincide with the gravity of the clinical manifestations.

4. Even in cases in which the clinical symptoms are severe, if the function excreting urea is intact, the prognosis is hopeful.

5. It is possible that cardiac failure in beriberi is due to an accumulation of some unknown toxic products in the blood, the elimination of which is coincident with the elimination of urea. 